\title{
Oxidative Stress Action in Cellular Aging
}

\author{
Monique Cristine de Oliveira ${ }^{1}$ and João Paulo Ferreira Schoffen ${ }^{2 *}$ \\ ${ }^{I}$ Departamento de Bioquímica; Universidade Estadual de Maringá; Avenida Colombo, 5790; 87020-900; Maringá - \\ PR - Brasil. ${ }^{2}$ Departamento de Biologia e Tecnologia; Universidade Estadual do Norte do Paraná; Campus Luiz \\ Meneghel; Rodovia BR-369 Km 54; 86360-000; Bandeirantes - PR - Brasil
}

\begin{abstract}
Various theories try to explain the biological aging by changing the functions and structure of organic systems and cells. During lifetime, free radicals in the oxidative stress lead to lipid peroxidation of cellular membranes, homeostasis imbalance, chemical residues formation, gene mutations in DNA, dysfunction of certain organelles, and the arise of diseases due to cell death and/or injury. This review describes the action of oxidative stress in the cells aging process, emphasizing the factors such as cellular oxidative damage, its consequences and the main protective measures taken to prevent or delay this process. Tests with antioxidants: vitamins $A, E$ and $C$, flavonoids, carotenoids and minerals, the practice of caloric restriction and physical exercise, seeking the beneficial effects on human health, increasing longevity, reducing the level of oxidative stress, slowing the cellular senescence and origin of certain diseases, are discussed.
\end{abstract}

Key words: Antioxidants, cellular aging, cell death, oxidative stress

\section{INTRODUCTION}

The manifestation of the aging phenomenon through life is changeable among the same as different species. There are a large number of definition of the biological aging that although differ in one or other way, share the notion of loss of functionability progressive with age, with the consequential increase of the susceptibility and disease incidence, increasing the possibility of death (Mota et al., 2004). Different biological theories about aging analyze the theme through the function and structure change of organic systems and cells (Gava and Zanoni, 2005). In general, these could be classified in two main categories. The first, of genetic nature, considers the aging as something genetically controlled, while the second, of stochastic nature, considers that aging depends on the amount of environmental aggressions (Farinatti, 2002).

Among the valid theories about the aging process, the most explored currently is the theory about oxidative stress, a stochastic hypothesis. In the human body there is formation of free radicals from oxygen in several metabolic process (Cotran et al., 2000a) and/or different environmental factors (Mota et al., 2004). Those molecules are eletronicaly unstable, therefore, highly reactive having the ability to react to a great number of components that are near them (Bianchi and Antunes, 1999). When an excessive production of free radicals ocurrs on a decrease of antioxidants agents, these start to have a prejudicial effect to the body components (Bianchi and Antunes, 1999; Novelli, 2005). In any of these situation, the excess of free radicals prevails, leading to the

\footnotetext{
*Author for correspondence: jpschoffen@uenp.edu.br
} 
oxidative stress, causing the death of many cells by necrosis or apoptosis, or start functioning in an inadequate way, altering tissue, organs and whole organism physiology, therefore unchaining cell aging process and the genesis of several diseases (Sohal and Weindruch, 1996).

There are reports about the action of oxidative stress in the cells aging process, giving the mechanisms involved in the cellular oxidative damage, the origin of some diseases caused by the injury or death of the cells and the main protective measures taken to prevent or delay this process.

\section{LITERATURE REVIEW}

\section{Cellular aging and oxidative stress}

Aging is a continuous process that begins at the of inception involving organism and its cells differentiation and maturation and, at a certain point in time, evolving to progressive damage of the functional capacity of the typical senescence and ends in death (Cotran et al., 2000b). According to Farinatti (2002), the changes in the internal means make organ systems to not perform their duties well. The ability to maintain the body liquid compartment in the stable condition is a determinant key for survival. Due to the deterioration of physiological mechanisms with age, the elderly respond slower and in less effective way to the environmental changes, making them more vulnerable to the diseases. The mechanisms that attempt to explain the aging must elucidate various conditions, including the loss of homeostasis maintenance in individual organisms at their final stage of life, and clarify the biological bases of the wide variation of time during the life of sexual partners, species and genetic lineages and also must demonstrate that the aging can be manipulated by the introduction of changes in various factors suspected as the cause of this process (Bonatto et al., 2004).

Bonatto et al. (2004) reported that an experiment based on nutritional deprivation in Drosophila melanogaster showed that the lifetime of an organism was the consequence of two variable functions, the first being the genetic constitution of the individual, called vitality, and the second, the individual metabolic intensity. The demonstration of oxygen consumption by the aerobic organisms and free radical generation were able to establish a connection between the theory of the rate of longevity, which suggested that the genetic constitution of the body determined the amount of energy consumed during its life expectancy and the hypothesis of oxidative stress, in which the excess of free radicals produced the cellular damage. According to Cerutti (1991), the formation of free radicals in vivo occurs via the catalytic action of enzymes during the process of transfer of electrons that occurs in cell metabolism and/or by exposure to exogenous factors such as radiation, cigarettes, paracetamol, paraquat herbicide or organic solvents.

The hypothesis of oxidative stress is the primary cause that links the loss of physiological functions with senescence, yet, these dysfunctions can be alleviated if there is a decrease in the generation of different types of reactive oxygen species (ROS) that promote the oxidative stress (Sohal and Weindruch, 1996). All the cells, regardless of the organism used as a model, exhibit some level of oxidative stress, and the amount of oxidative damage generated in various macromolecules such as lipids, proteins and DNA, increase exponentially during the aging in a variety of tissues in different species (Harman, 1956). Berlett and Stadtman (1997) described that while the oxidative damage in the lipids and DNA were functional consequences of the aging process, several pioneer studies demonstrated that protein oxidative damage could be the crucial factor of aging, leading to loss of catalytic activity and structural integrity of the protein. The oxidative damage that occurs in different proteins are targeted and not random events, a fact that particularly corroborates to demonstrate that the specificity of protein damage generated by free radicals is the basis to explain some of the physiological changes associated with aging (Yan et al., 2000).

\section{Free radicals, cell damage and morphophysiological changes}

According to Alves et al. (2005), free radicals are chemical species that have at least one unshared electron valence layer. Ferreira and Matsubara (1997) complement that the free radical term refers to the highly reactive atoms or molecules, which contain odd number of electrons in its last eletronic layer. It is this non-pairing of electrons of the last layer that confers high reactivity to these atoms or molecules. Ferreira and Matsubara (1997) and Alves et al. (2005) also showed that free radicals were formed in oxidation-reduction reactions, yielding the lone electron, letting it rust or get another, reducing it. 
Free radicals are important to protect the body against the foreign agents, helping neutrophils and macrophages activity, since they already have bactericidal activity by the oxidative degradation of lipids, proteins and microbial DNA (Alves et al., 2005). But despite the fundamental contribution of free radicals in the cellular defense mechanism, they might have a detrimental effect to the body, if there is an excessive increase or decrease in its antioxidants production. Table 1 shows the main ROS in the cells.

According to Deplabos and Gonzáles (2000), most free radicals are formed in the mitochondria during the production of energy from glucose and oxygen. Besides the mitochondrial origin, the body may be exposed to free radicals generated by the organic physical processes, such as unbalanced diet, excess alcohol, smoking and even by air pollution. The excess of free radicals leads to cell oxidation, which is considered the initial stage of various pulmonary, cardiac, vascular and neoplastic diseases. Free radicals act on cells by altering the molecular characteristics of the membranes, promoting gene mutations, disrupting the cellular homeostasis and collaborating in the formation of chemical residues and other compounds linked to the aging process (Caldeira et al., 1989).

Table 1 - Main oxygen reactive species and its performance.

\begin{tabular}{|c|c|c|c|c|}
\hline Species & $\begin{array}{l}\text { Chemical } \\
\text { Structure }\end{array}$ & Description & Occurence & Action \\
\hline $\begin{array}{l}\text { Superoxide } \\
\text { radical }\end{array}$ & $\mathrm{O}_{2}^{-}$ & $\begin{array}{l}\text { Most potent radical in the } \\
\text { induction of cellular damage }\end{array}$ & Almost all aerobic cells & $\begin{array}{l}\text { Majority of reactions } \\
\text { as a reducing agent }\end{array}$ \\
\hline $\begin{array}{l}\text { Hydroxyl } \\
\text { radical }\end{array}$ & $\mathrm{OH} \bullet$ & $\begin{array}{l}\mathrm{O}_{2}^{-} \text {acid conjugate, highly } \\
\text { reactive }\end{array}$ & $\begin{array}{l}\text { Formed through water } \\
\text { radiolysis }\end{array}$ & $\begin{array}{l}\text { DNA, proteins, } \\
\text { carbohydrates and lipids }\end{array}$ \\
\hline $\begin{array}{l}\text { Hydroperoxyl } \\
\text { radical }\end{array}$ & $\mathrm{HO}_{2} \bullet$ & Protonated form of the $\mathrm{O}_{2}^{-}$ & From hydrogen peroxide & Biological membranes \\
\hline $\begin{array}{l}\text { Hydrogen } \\
\text { peroxide }\end{array}$ & $\mathrm{H}_{2} \mathrm{O}_{2}$ & $\begin{array}{l}\text { It's not a free radical, because } \\
\text { did not submit electrons paired } \\
\text { in the last layer }\end{array}$ & $\begin{array}{l}\text { Reactions for the production } \\
\text { of } \mathrm{OH} \bullet\end{array}$ & Proteins and lipids \\
\hline $\begin{array}{l}\text { Singlet } \\
\text { oxygen }\end{array}$ & ${ }^{1} \mathrm{O}_{2}$ & $\begin{array}{c}\text { Excited form of molecular } \\
\text { oxygen. It's not a free radical, } \\
\text { because did not submit electrons } \\
\text { paired in the last layer }\end{array}$ & $\begin{array}{c}\text { Generated by phagocytes, } \\
\text { luminous induction and } \\
\text { catalyzed reactions by } \\
\text { peroxidases }\end{array}$ & DNA changes \\
\hline
\end{tabular}

Normally, the cells modified by the immune system would be eliminated from the body; however, when the amount of modified cells is increased by the excess of free radicals, the body can not eliminate these cells (Bianchi and Antunes, 1999, Mota et al., 2004). Alves et al. (2005) showed that some cells survived and worked in an inadequate way, altering the tissues, organs and the whole body physiology.

Despite the existence of endogenous antioxidant agents and mechanisms in cells, the excess formation of ROS with the oxidative stress lead to miscellaneous organ dysfunction. However, this condition varies according to the organisms, cell types, and even among the cells of the same tissue by the antioxidant capacity diversification (Berra et al., 2006). According to Berra et al. (2006), the main targets of ROS include lipids, proteins and DNA, and the preference of attack varies, depending on where the reactive species is generated, the availability of metal ions and biomolecules related to the relative ability of a biomolecule to be oxidized. Unlike the DNA, which is responsible for genetic information of all cells in the body, proteins and lipids can be removed by degradation.

According to Cotran et al. (2000a), the effects of reactive species are comprehensive. However, three reactions are relevant to cell damage. The first is the lipid peroxidation of membranes, which occurs when the double bonds in the unsaturated fatty acids of the membrane lipids are attacked by free radicals derived from oxygen, particularly the $\mathrm{OH} \bullet$ radical. The radical-lipid interactions generate peroxides, which are unstable and reactive, and survive an autocatalytic chain reaction, which can result in extensive damage of the organelles and cell membranes. The second reaction is the oxidative modification of proteins, which occurs due to the action of free radicals oxidizing the side chains of residues of amino acids, forming cross-linking protein-protein and 
oxidizing the protein skeleton, resulting in fragmentation of the biomolecule. The oxidative modification increases the degradation of critical enzymes for multicatalytic proteasome complex, causing havoc throughout the cell. Finally, lesions occur in DNA through the reactions with thymine in nuclear and mitochondrial DNA, producing single strand breaks in the DNA.

The presence of the endogenous pigment, lipofuscin, characterizes the cells abrasion and cellular aging. This compound consists of lipids and protein polymers associated with phospholipids, which suggests its derivation from the peroxidation of polyunsaturated lipids in cell membranes. The importance of this pigment is that it acts as a flag of damage by free radicals and lipid peroxidation and is not harmful to the cell. The lipofuscin appears in the cytoplasm in a perinuclear portion, like a brown-yellowed fine grain (Cotran et al., 2000b). According to Mota et al. (2004), all the factors that induce an increased formation of ROS, may disrupt the cellular homeostasis, particularly the mitochondrial homeostasis, which contributes to the increase in injuries and changes in cellular organelle, leading to the changes in energy production and maintenance of cells vital functions, such as breathing, osmotic regulation, communication, signaling and division. According to Berra et al. (2006), when the amount and type of damage exceeds the cells ability to restore, the normal cellular effective mechanisms could be seriously affected, causing the death of the cell, or incorporate changes in the genome, which is forwarded to future generations. Such mutations may also display genotoxic effects and, consequently, generate genomic instability and hence the emerging of cancer.

\section{Cell death, oxidative stress and disease origins}

According to Cotran et al. (2000a), a normal cell is confined within a narrow range of structure and function of their genetic metabolism programs, differentiation and specialization, and by the limitations of neighboring cells, and also by the availability of metabolic substrates. Excessive physiological stresses and some pathologic stimuli can cause different cellular physiological and morphological adaptations. If the limits of adaptive response to a stimulus are exceeded, or when the adjustment is impossible, a series of events occur, causing cell damage, which is reversible up to a limit, but if the stimulus is intense or continued from the beginning the cell reaches a point of no return and suffer irreversible injury followed by cell death. Pollard and Earnshaw (2006) describe that the accidental cell death, known as necrosis, occurs when a cell receives an ill chemical that causes structural or irreparable damage. Its main feature is the fact that the cells die because they are damaged and disintegrated and digested by its own lytic enzymes.

An initial cell death feature is the accidental loss of the plasma membrane integrity, so that there is an excessive influx of water in the cell, which swells until the cell membrane and the organelles break and thus the cell auto-digest and launches their cytoplasmic contents to the extracellular environment. This action causes a local inflammation by the accumulation of phagocytic cells that are activated by the ingestion of cellular debris, and usually involves large groups of neighboring cells (Pollard and Earnshaw, 2006).

The increase of ROS levels can lead to necrosis by causing the transition of mitochondrial permeability, disabling the power and recovery of cellular ATP. The ischemia may affect the antioxidant defense mechanisms of the cells accumulating free radicals by producing superoxide anions due to indirect and incomplete reduction of oxygen by amended mitochondria, or by the action of leukocytes oxidase and parenchymal cells (Freitas et al., 2002).

Another type of cell death is by apoptosis (silent cell death), designed to remove the unwanted cells from the host by activation of internally programmed events, those made by a group of gene products. The cell apoptosis occurs during the development, as a defense mechanism, a homeostatic process, which keeps the cells in tissues when they are damaged by pests, diseases or the aging process (Cotran et al., 2000a). According to Alberts et al. (2006), the cells that undergo apoptosis show reduction in their size, dense cytoplasm and compacted organelles, chromatin presents itself in an condensed and aggregated form under the nuclear membrane, and the nucleus can break into several fragments. There is surface bubbles formation in the fragmentation, forming apoptotic bodies which are phagocytized and replaced by the adjacent cells, occupying the space that migrate out of the cell.

Solá et al. (2001) reports that the changes arising from the apoptotic process are derived from successive events that lead, primarily, from the 
activation of cysteine protease, called caspase. According to these authors, the cells committed to apoptotic cell death remain under inactive proforms, called latent phase, until the activation of apoptotic process which occurs by proteolytic cleavage that makes the starting caspase activation, triggering the executing caspase. This cleaves a variety of essential proteins and substrates for cellular life, entering then the implementation phase. According to Pollard and Earnshaw (2006), during this stage the cells undergo the morphological and physiological changes, leading to death.

Silva and Silva (2005) reported that some studies showed that the action of ROS induced to apoptotic cell death during the aging process, because they caused changes in proteins, DNA and telomere. Horta and Young (1999) stated that both the excess and apoptotic failure affected the vital organic processes that could generate the diseases, which, according to Harman (1991) varied with each person due to genetic differences and exposure to certain environmental factors. Exposure to small doses of hydrogen peroxide or the accumulation of ROS by the reduction of glutathione induce to apoptosis in uncontrolled cell fungi, a fact indicating that the ROS are key regulators of apoptosis in this organism (Madeo et al., 1997).

According to Solá et al. (2001), the induction of apoptotic process may occur by hydrophobic bile acids, which probably held the release of cytochrome $\mathrm{C}$, originated from the oxidative stress, increasing the activity of specific caspase and leading to fragmentation of DNA, which triggers the characteristic biochemical apoptosis. Salvador et al. (2004) portray the existence of studies comparing the performance of oxidative stress, with the participation of ROS and the onset of diseases such as diabetes, atherosclerosis, cancer and neurovegetative diseases with age.

The oxidative stress when combined with diabetes mellitus, a disease caused by the deficiency of production and/or action of insulin, has an important participation in the pathogenesis of diabetic complications such as microangiopathy and neuropathy, and is therefore considered one of the mechanisms triggering this condition (Vicent et al., 2004). Baynes (1991) points out that other potential mechanisms may increase the power of oxidative stress in diabetes: the autoxidative glycosylation, the polyol pathway in the macroangiopathy related to hypoxia and changes in levels of inflammatory mediators. In atherosclerosis, chronic-degenerative disease that leads to blockage of arteries by accumulation of lipids in their walls (Carvalho Filho and Alencar, 2004; Papaléo Netto et al., 2004), may result, according to Salvador et al. (2004), by risk factors such as hypertension, smoking, diabetes, aging, physical inactivity, stress and high levels of blood cholesterol. Besides these factors, there is also the influence of reactive species in the development of this pathology. According to Wink and Mitchell (1998), the influence of nitric oxide in the genesis of atherosclerosis seems to be related to an environment rich in superoxide, which in the presence of peroxidases or superoxide, nitric oxide reacts rapidly to produce a variety of nitrogen reactive species (NRA). Carr et al. (2000) complement that the enzymes xanthine-oxidase, NADP $(\mathrm{H})$ and mitochondrial electron transport chain are potential producers of superoxide on the walls of arteries.

Another diseases that can be triggered by the action of free radicals are a benign and a malignant neoplasm (Salvador et al., 2004). Silva and Silva (2005) describe that neoplasia comes from the changes in the apoptotic process, or even in cell proliferation caused heterostasis, or a leak of temporary equilibrium, which favors the accumulation of disorderly cells in a tumor causing symptoms that characterize the cancer, which, according to Malzyner and Caponero (2004), incidence increases with age. According to Salvador et al. (2004), the ROS decisively cooperate in the mechanisms of carcinogenesis development, as these aggressors cause oxidative damage in the lipids, proteins and mainly in the nitrogen bases of DNA. Silva and Silva (2005) emphasize that the injury to the DNA molecule, especially in the genes mutation that control the proliferation of normal cells, results in homeostasis loss of tissue and disruption of the normal cellular events.

The non-transmissible chronic diseases of a neurological order such as Parkinson's, Alzheimer's disease and amyotrophic lateral sclerosis, may also have their origin connected with the action of oxidative stress (Salvador et al., 2004). According to Pearce et al. (1997), studies found that individuals with Parkinson's disease have high levels of total iron in the substantia nigra, located inside the cerebral hemisphere, showed a reduction in the levels of reduced glutathione, endogenous antioxidant enzyme. Both records can lead and increase the generation of 
free radicals such as hydrogen peroxide and hydroxyl radical. High levels of lipids peroxidation and catalase enzymes, superoxide dismutase and glutathione peroxidase were found in various regions of the brain of individuals with Alzheimer's (Pappolla et al., 1992). Moreover, high levels of 8-hydro-deoxyguanosine (8-OHdG), a mutagenic product produced in DNA by different ROS, and nitrotyrosine, an oxidated amino acid were also evidenced (Nunomura et al., 2001).

In relation to amyotrophic lateral sclerosis, Pedersen et al. (1998) report studies that associated oxidative stress with the pathogenesis of the disease, due to the verification of increased concentration of aldehyde 4-hydroxy-2transnonenal of $8-\mathrm{OHdG}$ and nitrotyrosine in patients with the disease. The presence of enzymes that degrade the nucleotides, ATP, ADP and AMP in non-transferable chronic diseases of neurological order indicate the involvement of oxidative stress in the genesis of the disease, since the brain consumes high amounts of oxygen and is susceptible to the oxidative stress because the metabolism of neurotransmitters such as glutamate and dopamine, which generates ROS, consume the antioxidant defenses, causing lipid peroxidation of neuronal membranes as well as changes in cellular homeostasis (Salvador et al., 2004).

\section{Antioxidants and prevention}

There are differences regarding the extent of life and the pace of aging, considering that the maximum life duration is immutable and aging rate is unalterable. However, some researchers do not agree with this. Papaléo Netto and Borgonovi (2005) reported that some factors influenced the aging process delaying it. Cotran et al. (2000a) and Novelli (2005) explain that the antioxidants are molecules that have the ability to reduce, protect or prevent the expansion of the oxidative damage in biomolecules, that is, they hold the trigger of the free radicals production and inactivate or prevent the generation of damage by them.

The cell posseses an antioxidant defense system to protect itself (Ferreira and Matsubara, 1997). Novelli (2005) suggests that there are two basic lines of antioxidants: the antioxidant enzymes, which correspond to enzymes of the glutathione, catalase and peroxide dismutase, and those nonenzymatic antioxidants, such as certain types of vitamins such as ascorbic acid and tocopherol, and endogenous components such as bilirubin. Ferreira and Matsubara (1997) subdivided these lines into two groups. The first, with and detox action by agents, acting before they cause any harm, being composed by the enzymes superoxide dismutase, catalase, glutathione peroxidase and vitamin E. And the second group that repairs the injury occurred, is composed by the enzymes glutathione reductase and glutathione peroxidase and ascorbic acid. Table 2 presents the main enzymes that act in the biological processes against the cell oxidative damage.

Table 2 - Antioxidant defense system of cell enzymes, their biological and main sites of action.

\begin{tabular}{|c|c|c|}
\hline Enzyme (Symbol) & Biological Actions & Sites \\
\hline $\begin{array}{l}\text { Superoxide dismutase } \\
\text { (Sod) }\end{array}$ & $\begin{array}{c}\text { Catalyses the dismutation from } \mathrm{O}_{2}^{-} \text {to } \mathrm{H}_{2} \mathrm{O}_{2} \text {, that is less reactive } \\
\text { and can be degraded by other enzymes }\end{array}$ & Abundant in aerobic cells \\
\hline Catalase (Cat) & Catalyses water and oxygen formation from $\mathrm{H}_{2} \mathrm{O}_{2}$ & $\begin{array}{l}\text { Erythrocytes and spleen, } \\
\text { mammals kidney and liver }\end{array}$ \\
\hline $\begin{array}{l}\text { Glutathione peroxidase } \\
\text { (GSH-Px) }\end{array}$ & $\begin{array}{l}\text { Catalyses the reduction of } \mathrm{H}_{2} \mathrm{O}_{2} \text { and organic peroxides to their } \\
\text { correspondent alcohol to the cost of convertion form reduced } \\
\text { glutathione (GSH) to oxidated gluathinone (GSSG) }\end{array}$ & Cytosol \\
\hline $\begin{array}{l}\text { Glutathione reductase } \\
\text { (GSH-Rd) }\end{array}$ & $\begin{array}{l}\text { Keeps the cells protection system incorrupt by reducing GSSG to } \\
\text { GSH }\end{array}$ & Liver and linfonods \\
\hline
\end{tabular}

Source: adapted from Borella and Varela (2004).

According to Baynes (1991), the oxidative stress is increased not only by high production of precursors of ROS, but may also be emphasized by low efficiency of enzymatic systems that control them. As mentioned before, the origin of certain diseases and/or organic dysfunction during the aging can be the outcome of oxidative stress increase on cells. However, this can be prevented if certain measures are taken. There is clear concern to establish a preventive measure to mitigate or combat the organic changes promoted by the oxidative stress in aging (Aranha et al., 2000, Cotran et al., 2000b; Farinatti, 2002; Koury and Donangelo, 2003; Zoppi et al., 2003; Kehl and 
Cassini, 2004; Burneiko et al., 2005; Diniz et al., 2005a; Faine et al., 2005; Galhardi et al., 2005; Gomes et al., 2005; Novelli Filho and Novelli, 2005; Souza Jr et al., 2005).

Cotran et al. (2000b) and Farinatti (2002) propose that a lower caloric intake tends to absorb the cell damage process during the aging because such measures like reduced calories would promote the reduction of lipid peroxidation, lowest accumulation of oxidized protein and reduce the oxidative damage of DNA, which extended the maximum term of mammalians life.

According to Faine et al. (2005), the proposal to establish a calorie limit would only produce the beneficial effects on health: increasing the longevity, reducing the toxicity caused by the drugs, improvement of organizational response to toxic processes, inhibition of carcinogenesis, and also reduce the level of oxidative stress. However, this influence is not yet fully established. Despite extensive investigations, the effects of calorie restriction have not been analyzed according to the amount and type of nutrient present in the diet. It's convenient to remember that great part of the population, in an attempt to reduce the food intake, restricts the amount of food ingested, forgetting of the diet components qualify (Diniz et al., 2005a).

Due to the possible relation among dietary restriction, oxidative stress and cardiovascular disorders, the study of the effects of the caloric restriction on lipid rich diets is very important, since this kind of diet has many effects on heart tissue, as long as the type of fatty acid present on the diet is related to the composition of phospholipids on myocardium cell membranes (Diniz et al., 2005a). In general, the consumption of the diets rich in fatty acids with double links change the content of membrane fatty acids, favoring the presence of unsaturated lipids and increasing the susceptibility to lipoperoxidation.

Some flavonoids, the flavonols, flavones and catechins, found in the fruits, vegetables, whole grains and grasses, have been also used in medicine against osteoporosis and inflammation, because they inhibit the precaution of the prostaglandin, diminishing the synthesis of nitric oxid, having a very important antioxidant characteristic (Bianchi and Antunes, 1999; Novelli Filho and Novelli, 2005). Fernandes et al. (2009) reported that the level of triacylglycerols, total cholesterol and LDL in the serum of the diabetic rat groups administred naringerin was lower than in the diabetic rat group, showing that the flavonoids decreased the triacyglycerols and total cholesterol in the rats blood. Diniz et al. (2005b) found that fiber had also an antioxidant effect. Gomes et al. (2005) considered vitamins C and E and carotenoids as exogenous antioxidants, since they were captivators of free radicals and some products of metabolism such as bilirubin and uric acid.

According to Aranha et al. (2000), vitamin C acts sweeping free radicals and nourishing the cells, and, therefore, essential to human metabolism. It can be found in the foods such as the citrus (citric) fruits, tomatoes, strawberries, sweet-peppers and broccoli. Studies by Bianchi and Antunes (1999) showed a protective role of the vitamin in preventing the development of tumors. However, its recommendation should be specific to each case, because the organic and inorganic components of the cell can affect its antioxidant action. In the experiments with diabetic rats, Zanoni et al. (2007) showed that plasmatic level of ascorbic acid suffered a reduction in the group of diabetic animals, when compared to the control group. It was likely that this reduction happened due to the oxidative stress, which promoted an increase on the free radicals frequency and a decrease on the substances responsible for fighting them, the antioxidants. The tissue concentrations of ascorbic acid also reduced because its transport was inhibited during hyperglycaemia.

Vitamin E can be found in the vegetable oils in varying forms; such as G-tocopherol, Dtocopherol, B-tocopherol and A-tocopherol (the latter is a form of antioxidants widely distributed in the tissues and plasma). These vitamins prevent the spread of reaction induced by the free radicals on the biological membrane minimizing the damage associated with the cancer, arthritis and aging (Bianchi and Antunes, 1999). Spada and Silva (2004) described that the carotenoids were the precursor of vitamin $\mathrm{A}$, the most important being B-carotene, found in spinach, carrots, pumpkin, mango, papaya and beets. Vitamin A may have an antioxidant or pro-oxidant role, because the carotenoids influence the singlet oxygen, inhibiting lipid peroxidation and sweeping the free radicals. However, under high oxygen pressure, they lose their antioxidant activity.

The use of minerals, such as zinc and selenium, with an antioxidant role, is linked to the dependence of antioxidant enzymes by these minerals. The superoxide dismutase depends on copper and zinc and the gluthathione dismutase on 
selenium. The reduced levels of this minerals results in susceptibility to oxidative damage on the cells and promotes the process of carcinogenesis (Bianchi and Antunes, 1999). These minerals establish an indirect action. As an antioxidant, zinc regulates the expression of methollothioneins and protection of sulfhydryl groups of membrane proteins (Koury and Donangelo, 2003).

According to Kehl and Cassini (2004), the physical activity has been able to mitigate the risk of many diseases. Burneiko et al. (2005) described that regular physical exercise has been strategy to reduce the deleterious effects of high intake calories, and to exercises work, mainly in reducing the concentration of triacylglycerol, total cholesterol, low density lipoprotein (LDL) and the increase in high-density lipoprotein (HDL).Thus, physical exercises decreases, for example, the risk of cardiovascular disorders, because it normalizes the lipid profile, promoting the fat oxidation and reducing the deleterious effects of the hypercaloric diet.

In contrast, as the mitochondrial oxygen flow should be high for the production of ATP during the exercise, the increase of the production of ROS may occur, which could lead to oxidative damage. The same way, changes in the diet components, like the substracts to obtain energy, are also associated to oxidative stress (Burneiko et al., 2005).

The imposition made by modern lifestyle that limits the time spent on feeding results in the ingestion of varying caloric content diets and the practice of physical exercises of different intensities (Schneider and Oliveira, 2004). To evaluate the resistance to exercise, the improvement of lipid profile and weight loss, the effect of different types of diets associated with physical activity have been subject of several and frequent studies. However, the effects of the interaction between the hipercaloric diet intake and practice of physical exercises in oxidative stress and energy metabolism have not been well established.

A balanced diet coupled with daily exercise promotes the beneficial effects, reducing the lipid serum profile and the myocardic lipid peroxidation. On the other hand, a hypercaloric diet associated with inactivity leads to dyslipidemia, which can be normalized by the exercise. When physical exercise is performed daily, the normalization of the serum lipid profile is obtained even when associated to hypercaloric diet, although, in this condition, increase of mycordial lipid peroxidation occurs (Schneider and Oliveira, 2004).

\section{CONCLUSION}

There are many theories that attempt to explain the mechanisms involved in the biological aging. However, none of them provide full and definite reasons for the development of such phenomenon. In the oxidative stress theory, it's possible to verify that the cells are constantly exposed to possible damage caused by the ROS: lipid peroxidation, unbalance of homeostasis cell, chemical residues formation, genes mutations in DNA dysfunction from certain organelles, diseases may appearing due to injury and/or cell death.

The tests performed with non-enzymatic antioxidants (vitamins A, E, C, flavonoids, carotenoids and minerals) and calorie restriction and physical exercises had been proved as beneficial alternatives to reduce, protect, and prevent the expansion of biomolecules oxidative damages and cell aging. However, very little is found regarding the employment of these factors in the treatment of diseases triggered and/or exacerbated by the action of oxidative stress.

Just like bodily systems balanced and coordinated interrelationship, the theory of oxidative stress, the focus of this work, and other existing theories shouldn't be evaluated in isolation but in a broader context because, despite the variety of mechanisms mentioned, all the strategies have not been proved yet. Further studies need to focus on the phenomenon of aging.

However, it could be concluded that the oxidative stress theory is an obvious cause that links the physiological function loss to cell senescence, since it leads to many cells death or injury. This is very important to emphasize that not only this theory still requires its final conclusion, just like all the other theories presented, but there is need of new investigations regarding the use of antioxidants nutrients and other potential protective measures that may help in the treatment and prevention of diseases related to aging.

\section{RESUMO}

Diferentes teorias tentam explicar o envelhecimento biológico através da alteração das 
funções e estrutura dos sistemas orgânicos e células. Ao longo da vida, os radicais livres presentes no estresse oxidativo conduzem à peroxidação dos lipídios das membranas celulares, desequilíbrio da homeostase, formação de resíduos químicos, mutações gênicas no DNA, disfunção de certas organelas, bem como ao surgimento de doenças devido à lesão e/ou morte celular. Nesta revisão descreve-se a ação do estresse oxidativo no processo de envelhecimento das células, enfatizando fatores como os danos oxidativos celulares, suas consequiências e as principais medidas protetoras adotadas para se prevenir ou retardar este processo. Testes com antioxidantes: vitaminas A, E e C, flavonóides, carotenóides e minerais; a prática de restrição calórica e exercícios físicos, que buscam efeitos benéficos sobre a saúde humana, aumentando a longevidade, reduzindo o nível de estresse oxidativo, retardando a senescência celular e a origem de certas doenças, são discutidos.

\section{REFERENCES}

Alberts, B.; Bray, D.; Lewis, J.; Johnson, A.; Raff, M.; Roberts, K; Walter, P.; Hopkin, K. (2006), Controle do ciclo celular e morte celular. In-Fundamentos da biologia celular, ed. Alberts, B.; Bray, D.; Lewis, J.; Johnson, A.; Raff, M.; Roberts, K; Walter, P.; Hopkin, K. Artmed, Porto Alegre, pp. 625-634.

Alves, J.A.N.R.; Luz, J.; Guerra, K.A.; Santello, L.C.; Serwes, N.; Santos, R.S.A. (2005), Envelhecimento normal, UFSC - Centro de Ciências da Saúde, Florianópolis, pp. 151.

Aranha, F.Q.; Barros, Z.F.; Moura, L.S.A.; Gonçalves, M.C.R.; Barros, J.C.de.; Metri, J.C.; Souza, M.S.de. (2000), $\mathrm{O}$ papel da vitamina $\mathrm{C}$ sobre as alterações orgânicas no idoso. Rev. Nutr., 13, 89-97.

Baynes, J.W. (1991), Role of oxidative stress in development of complications in diabetes. Diabetes, 40, 405-412.

Berlett, B.S.; Stadtman, E.R. (1997), Protein oxidation in aging, disease, and oxidative stress. J. Biol. Chem., 272, 20313-20316.

Berra, C.M.; Menck, C.F.M.; Mascio, P. (2006), Estresse oxidativo, lesões no genoma e processos de sinalização no controle do ciclo celular. Quím. Nova, 29, 1340-1344.

Bianchi, M.L.P.; Antunes, L.M.G. (1999), Radicais livres e os principais antioxidantes da dieta. Rev. Nutr., 12, 123-130.

Bonatto, D.; Rosa, R.M.; Saffi, J.; Henriques, J.A.P. (2004), Estresse oxidativo e envelhecimento. In-Radicais livres e a resposta celular ao estresse oxidativo. ed. Salvador, M.; Henrique, J.A.P. da Ulbra, Canoas, pp. 185-200.

Borella, M.L.L; Varela, Q.D. (2004), Antioxidantes enzimáticos. In-Radicais livres e a resposta celular ao estresse oxidativo. ed. Salvador, M.; Henrique, J.A.P. da Ulbra, Canoas, pp. 35-50.

Burneiko, R.C.M.; Diniz, Y.S.; Galhardi, C.M.; Faine, L.A.; Rodrigues, H.G.; Ebaid, G.M.X; Novelli, E.R.B. (2005),
Dieta hipercalórica, exercício físico e perfil lipídico. InNutrição e vida saudável: estresse oxidativo e metabolismo energético. ed. Novelli, E.L.B. Tecmedd, Ribeirão Preto, pp. 177-189.

Caldeira, A.M.L.; Paulino, N.A.; Aymoré, L.I.; Chahon, V.L. (1989), As bases biológicas do envelhecimento. Folha Méd., 99, 107-118.

Carr, A.C.; McCall, M.R.; Frei, B. (2000), Oxidation of LDL by myeloperoxidases and reactive nitrogen species: reaction pathways and antioxidant protection. Arterioscler. Thromb. Vasc. Biol., 20, 1716-1723.

Carvalho Filho, E.T.; Alencar, Y.M.G. de. (2004), Teorias do envelhecimento. In-Geriatria: fundamentos, clínica $e$ terapêutica. ed. Carvalho Filho, E.T.; Papaléo Netto, M. Atheneu, São Paulo, pp. 1-8.

Cerutti, P.A. (1991), Oxidant stress and carcinogenesis. Eur. J. Clin. Invest., 21, 1-5.

Cotran, R.S.; Kumar, V.; Collins, T. (2000a), Patologia celular I: lesão e morte da célula. In-Robbins: patologia estrutural e funcional. ed. Cotran, R.S.; Kumar, V.; Collins, T. Guanabara Koogan, Rio de Janeiro, pp. 1-26.

Cotran, R.S.; Kumar, V.; Collins, T. (2000b), Patologia celular II: adaptações, acúmulos intracelulares e envelhecimento celular. In-Robbins: patologia estrutural $e$ funcional. ed. Cotran, R.S.; Kumar, V.; Collins, T. Guanabara Koogan, Rio de Janeiro, pp. 27-43.

Deplabos, B.B.; González, A.E. (2000), Envejecimiento vs. Radicales libres. Rev. Fac. Farm. (Merida), 38, 20-26.

Diniz, Y.S.; Burneiko, R.C.M.; Faine, L.A.; Galhardi, C.M.; Rodrigues, H.G.; Novelli, E.L.B. (2005a), Restrição alimentar e dietas ricas em ácidos graxos. In-Nutrição $e$ vida saudável: estresse oxidativo e metabolismo energético. ed. Novelli, E. L. B. Tecmedd, Ribeirão Preto, pp. 145-155.

Diniz, Y.S.; Burneiko, R.C.M.; Faine, L.A.; Galhardi, C.M.; Rodrigues, H.G.; Novelli, E.L.B. (2005b), Fibras: efeitos na síndrome metabólica e estresse oxidativo. In-Nutrição e vida saudável: estresse oxidativo e metabolismo energético. ed. Novelli, E. L. B. Tecmedd, Ribeirão Preto, pp. 167-176.

Faine, L.A.; Galhardi, C.M.; Diniz, Y.S.; Burneiko, R.C.M.; Rodrigues, H.G.; Novelli, E.L.B. (2005), Restrição dietética: efeitos sobre o metabolismo energético cardíaco. In-Nutrição e vida saudável: estresse oxidativo e metabolismo energético. ed. Novelli, E. L. B. Tecmedd, Ribeirão Preto, pp. 137-144.

Farinatti, P.T.V. (2002), Teorias biológicas do envelhecimento: do genético ao estocástico. Rev. Bras. Med. Esporte, 8, 129-137.

Fernandes, A.A.H.; Novelli, E.L.B.; Fernandes Junior, A.; Galhardi, C.M. (2009), Effect of naringerin on biochemical parameters in the streptozotocin-induced diabetic rats. Braz. Arch. Biol. Technol., 52, 51-59.

Ferreira, A.L.A.; Matsubara, L.S. (1997), Radicais livres: conceitos, doenças relacionadas, sistema de defesa e estresse oxidativo. Rev. Ass. Med. Bras., 43, 61-68.

Freitas, F.A.S. de.; Piccinato, C.E.; Campos, A.D.; Cherri, J. (2002), Estudo da isquemia e reperfusão em retalhos cutâneos de ratos. Acta Cir. Bras., 17, 74-78.

Galhardi, C.M.; Faine, L.A.; Burneiko, R.C.M.; Diniz, Y.S.; Rodrigues, H.G.; Ribas, B.O.; Novelli, E.L.B. (2005), Propriedades do cobre na dieta. In-Nutrição e vida saudável: estresse oxidativo e metabolismo energético. ed. Novelli, E. L. B. Tecmedd, Ribeirão Preto, pp. 205-213. 
Garcez, M.; Bordin, D.; Peres, W.; Salvador, M. (2004), Radicais livres e espécies reativas. In-Radicais livres e a resposta celular ao estresse oxidativo. ed. Salvador, M.; Henrique, J.A.P. da Ulbra, Canoas, pp. 13-33.

Gava, A.A.; Zanoni, J.N. (2005), Envelhecimento celular. Arq. Ciênc. Saúde UNIPAR, 9, 41-46.

Gomes, M.M.; Sauders, C.; Accioly, E. (2005), Papel da vitamina A na prevenção do estresse oxidativo em recémnascidos. Rev. Bras. Saude Mater. Infant., 5, 275-282.

Harman, D. (1956), Aging: a theory based on free radical and radiation chemistry. J. Gerontol., 11, 298-300.

Harman, D. (1991), The aging process: major risk factor for disease and death. Proc. Natl. Acad. Sci. U.S.A, 88, 53605363.

Horta, M.F.; Young, J.D. (1999), Apoptose: quando a célula programa a própria morte. Ciência Hoje, 25, 38-43.

Kehl, L.F.L.; Cassini, C. (2004), Exercício físico e estresse oxidativo. In-Radicais livres e a resposta celular ao estresse oxidativo. ed. Salvador, M.; Henrique, J.A.P. da Ulbra, Canoas, pp. 111-137.

Koury, J.C.; Donangelo, C.M. (2003), Zinco, estresse oxidativo e atividade física. Rev. Nutr., 16, p. 433-441.

Madeo, F.; Fröhlich, E.; Fröhlich, K. (1997), A yeast mutant showing diagnostic markers of early and late apoptosis. $J$. Cell Biol., 139, 729-734.

Malzyner, A.; Caponero, R. (2004), Câncer na terceira idade. In-Geriatria: fundamentos, clínica e terapêutica. ed. Carvalho Filho, E.T. de.; Papaléo Netto, M. Atheneu, São Paulo, pp. 345-351.

Mota, P.; Figueiredo, P.A.; Duarte, J.A. (2004), Teorias biológicas do envelhecimento. Rev. Port. Cien. Desp., 4, 81-110.

Novelli, E.L.B. (2005), Radicais livres e estresse oxidativo. In-Nutrição e vida saudável: estresse oxidativo $e$ metabolismo energético. ed. Novelli, E. L. B. Tecmedd, Ribeirão Preto, pp. Ribeirão Preto: Tecmedd, pp. 93-113.

Novelli Filho, J.L.V.B.; Novelli, E.L.B. (2005), Estresse oxidativo e inflamação: o efeito de antiinflamatórios. InNutrição e vida saudável: estresse oxidativo e metabolismo energético. ed. Novelli, E. L. B. Tecmedd, Ribeirão Preto, pp. 131-135.

Nunomura, A.; Perry, G.; Aliev, G.; Hirai, K.; Takeda, A.; Balraj, E.K.; Jones, P.K.; Ghanbari, H.; Wataya, T.; Shimohama, S.; Chiba, S.; Atwood, C.S.; Petersen, R.B.; Smith, M.A. (2001), Oxidative damage is the earliest event in Alzheimer disease. J. Neuropathol. Exp. Neurol., 60, 759-767.

Papaléo Netto, M.; Borgonovi, N. (2005), Biologia e teorias do envelhecimento. In-Gerontologia: a velhice $e \quad o$ envelhecimento em visão globalizada. ed. Papaléo Netto, M. Atheneu, São Paulo, pp. 44-59.

Papaléo Netto, M.; Figueira, J.L.; Carvalho Filho, E.T. de. (2004), Aterosclerose. In-Geriatria: fundamentos, clínica e terapêutica. ed. Papaléo Netto, M. Carvalho Filho, E.T. de.; Papaléo Netto, M. Atheneu, São Paulo, pp. 97-100.

Pappolla, M.A.; Omar, R.A.; Kim, K.S.; Robakis, N.K. (1992), Immunohistochemical evidence of antioxidant stress in Alzheimer's disease. Am. J. Pathol., 140, 621-628.
Pearce, R.K.B.; Owen, A.; Daniel, S.; Jenner, P.; Marsden, C.D. (1997), Alterations in the distribution of glutathione in the substancia nigra in Parkinson's disease. J. Neural Transm., 104, 661-677.

Pedersen, W.A.; Weiming Fu; Keller J.N.; Markesbery, W.R.; Appel, S.; Smith, R.; Kasarskis, E.; Mattson, M.P. (1998), Protein modification by the lipid peroxidation product 4hydroxynonenal in the spinal cords of amyotrophic lateral sclerosis patients. Ann. Neurol., 44, 819-824.

Pollard, T.D.; Earnshaw, W.C. (2006), Morte celular programada. In-Biologia Celular. ed. Pollard, T.D.; Earnshaw, W.C. Elsevier, Rio de Janeiro, pp. 753-768.

Salvador, M.; Poletto, N.P.; Andreazza, A.C.; Soares, D.G. (2004), Estresse oxidativo e doenças. In-Radicais livres e a resposta celular ao estresse oxidativo. ed. Salvador, M.; Henrique, J.A.P. da Ulbra, Canoas, pp. 69-110.

Schneider, C.D.; Oliveira, A.R. de. (2004), Radicais livres de oxigênio e exercício: mecanismos de formação e adaptação ao treinamento físico. Rev. Bras. Med. Esporte, 10, 308313.

Silva, M.M. da.; Silva, V.H. da. (2005), Envelhecimento: importante fator de risco para o câncer. Arq. Méd. ABC, 30, 11-17.

Sohal, R.S.; Weindruch, R. (1996), Oxidative stress, caloric restriction, and aging. Science, 273, 59-63.

Solá, S.; Pedro, T.; Ferreira, H.; Rodrigues, C.M.P. (2001), Apoptose: uma questão de vida ou de morte. Biologias, 2, 1-7.

Souza Jr, T.P. de; Oliveira, P.R. de; Pereira, B. (2005), Exercício físico e estresse oxidativo: efeitos do exercício físico intenso sobre a quimioluminescência urinária e malondialdeído plasmático. Rev. Bras. Med. Esporte, 11, 91-95.

Spada, P.K.W.D.S.; Silva, C.O. da. (2004), Antioxidantes não enzimáticos. In-Radicais livres e a resposta celular ao estresse oxidativo. ed. Salvador, M.; Henrique, J. A. P. da Ulbra, Canoas, pp. 51-63.

Vicent, A.M.; Russell, J.W.; Low, P.; Feldman, E. (2004), Oxidative stress in the pathogenesis of diabetic neuropathy. Endocr. Rev., 25, 612-628.

Wink, D. A.; Mitchell, J. B. (1998), Chemical biology of nitric oxide: insights into regulatory, cytotoxic, and cytoprotective mechanism of nitric oxide. Free Radic. Biol. Med., 25, 434-456.

Yan, L.; Levine, R.; Sohal, R.S. (2000), Effects of aging and hyperoxia on oxidative damage to cytochrome $\mathrm{c}$ in the housefly, Musca domestica. Free Radic. Biol. Med., 29, 9097.

Zanoni, J.N.; Pereira, R.V.F.; Freitas, P.de. (2007), Effect of the ascorbic acid treatment on the NADHd-positive myenteric neurons of diabetic rats proximal colon. Braz. Arch. Biol. Technol., 50, 31-38.

Zoppi, C.C.; Antunes-Neto, J.; Catanho, F.O.; Goulart, L.F.; Motta e Moura, N.; Macedo, D.V.de. (2003), Alterações em biomarcadores de estresse oxidativo, defesa antioxidante e lesão muscular em jogadores de futebol durante uma temporada competitiva. Rev. Paul. Educ. Fís., 14, 119-130.

Received: April 06, 2009; Revised: September 14, 2009; Accepted: June 17, 2010 